\title{
Production of hairy root cultures of lettuce [Lactuca sativa L.)
}

\section{Research Article}

Tadić Vojin*1, Milošević Snežana1, Cingel Aleksandar¹, Petrić Marija1, Trifunović Milana1, Antonić Dragana1, Tadić Jovan², Subotić Angelina

${ }^{1}$ Department of Plant Physiology, Institute for Biological Research „Siniša Stankovic“", University of Belgrade, 11060 Belgrade, Serbia

${ }^{2}$ Department of Global Ecology, Carnegie Institution for Science, Stanford, CA 94305, USA

Received 2 December 2013; Accepted 5 March 2014

Abstract: Hairy root cultures of lettuce (Lactuca sativa L.) were obtained by inoculation of cotyledonary leaves of in vitro lettuce seedlings (cvs. Nansen and Ljubljanska ledenka) with Agrobacterium rhizogenes A4M70GUS. Approximately in $96.7 \%$ cvs. Nansen and in $91.2 \%$ Ljubljanska ledenka inoculated explants produced hairy root when they were incubated on Murashige and Skoog (MS) half-strength medium without plant growth regulators. A total of $54 \%$ of all hairy root cultures expressed GUS activity. Every hairy root represented an independent transformation event. Line Ljubljanska ledenka 18 showed the highest biomass ( 5.5 times the biomass of control root). A PCR analysis of the genomic DNA confirmed the presence of marker and target genes in 15 hairy roots examined.

Keywords: Genetic Transformation • Agrobacterium Rhizogenes • Lettuce

(C) Versita Sp. z 0.0 .

\section{Abbreviations}

GUS - ß-glucuronidase;

MS - Murashige and Skoog medium;

X-Gluc - 5-bromo-4-chloro-3-indolyl-B-D-glucuronide

\section{Introduction}

Lettuce (Lactuca sativa L.) is an annual plant, a leafy vegetable grown on nearly all continents. Lettuce (family Asteraceae) is believed to have originated from the Mediterranean. The evidence from Egyptian tomb paintings indicates that it was cultivated before 4500 $B C$. Lettuce classification is based on leaf shape and heading characteristics, though recently they have also been classified according to cropping seasons [1]. World lettuce production has been constantly increasing over the last years [2]. For instance, China produces almost half of the world's lettuce output, which amounts to 11 million Mt and is twice the size of the US output [3].

Genetic transformation is now a well-established technology. Like many other technologies, it has gone through different stages of evolution; scientific curiosity, research tool, novel applications and mass exploitation. The possibility using achievements in genetic engineering in scientific and applied medicine, veterinary and environmental science, seems very interesting. In this study genetic transformation with Agrobacterium rhizogenes was used for the introduction of exogenous genes into lettuce plants. A. rhizogenesmediated infection of the plant tissue cultures received some attention 70 years ago as attempts were made to develop in vitro systems to study bacterial pathogenesis and hairy root [4]. Hairy root cultures have many advantages including biochemical and genetic 
stability, independence from seasonal and geographical conditions, rapid growth, and the ability to produce secondary metabolites at the levels comparable to those of the plants grown naturally. A. rhizogenes is used as genetic sources to create new genotypes and phenotypes with increased branching, wrinkled leaves, shorted internodes and modified flowering [5]. As a result, these cultures have been used to produce pharmaceuticals, cosmetics and food additives from many plant species [6-8]. Shih and Doran [9] demonstrated that hairy root is a feasible mean for in vitro propagation of plant virus, epitope vaccines and foreign proteins. Also, hairy root has a significant role in phytoremediation, a process that can remove or reduce the concentration of toxic organic and inorganic pollutants in soil, water and industrial effluents [7,10-16] (Figure 1).

Lettuce transformation is an effective tool for a lettuce breeding program [17]. Since Pillegi et al. [18], Ahmed et al. [19], Matvieieva et al. [20] and Lim et al. [17] reported $A$. tumefaciens transformation of lettuce we have developed the transformation with $A$. rhizogenes for the first time. The aim of this work is to exploit in vitro hairy roots of lettuce as a base for the development of phytoremediation systems - uptake phenols from water (mini bioreactor or hydroponics system for growing plants - after developing system for plant regeneration from hairy root).

\section{Material and methods}

\subsection{Plant material and culture conditions}

The seeds of L. sativa c.v. Nansen and Ljubljanska ledenka (Semenarna, Ljubljana) were sterilized in commercial bleach solution containing $5 \%(\mathrm{v} / \mathrm{v})$ sodium hypochlorite for $15 \mathrm{~min}$, followed by washing with sterile distilled water three times. The seeds were placed on half-strength basal MS medium (Murashige and Skoog, 1962) with $30 \mathrm{gl}^{-1}$ sucrose, $100 \mathrm{mgl}^{-1}$ myo-inositol, $7 \mathrm{gl}^{-1}$ agar, pH 5.8 (25 ml/9 cm Petri dish; 20-30 seeds/dish). Seeds were germinated at $24 \pm 2{ }^{\circ} \mathrm{C}$ (under fluorescent light of $40 \mu \mathrm{mol} \mathrm{m} \mathrm{m}^{-2} \mathrm{~s}^{-1} 16 \mathrm{~h}$ light / $8 \mathrm{~h}$ dark photoperiod). Cotyledonary leaves of 7 -days old seedlings were used for the transformations.

\subsection{Preparation of $A$. rhizogenes inoculum and induction of hairy roots}

A. rhizogenes A4M70GUS carries the pRiA4 plasmid. This plasmid contains two T-DNA: $T_{L}$ and $T_{R}$ (Figure 2). The $T_{R}$-DNA consists of genes (aux1 and aux2) that control opine and auxin biosynthesis. The $T_{L}-D N A$ consists of four loci (rolA, ro/B, ro/C and ro/D). This was sufficient for producing the hairy root. The $T_{L}$-DNA has also uidA sequence (between ro/C and ro/D) driven by the 35S CaMV (Cauliflower mosaic virus) promoter followed by the nopaline synthase (nos) polyadenylation signal. uidA is reporter gene for enzyme $ß$-glucuronidase.

A. rhizogenes A4M70GUS were incubated on YEB medium (Yeast Extract Broth, [21]) pH 7.2, supplement with $100 \mathrm{mgl}^{-1}$ neomycin. The bacterial strain was grown in darkness for $48 \mathrm{~h}$ at $24 \pm 2^{\circ} \mathrm{C}$ and cultures were maintained at $4^{\circ} \mathrm{C}$. Prior to co-cultivation with plant tissue, $A$. rhizogenes A4M70GUS were cultured in the same liquid media overnight at $28^{\circ} \mathrm{C}$. Cotyledonary leaves were cut and incubated for $10 \mathrm{~min}$ in the bacterial suspension $\left(O D_{600}\right.$ of 0.6$)$, dried with blotting paper, and cultivated on half-strength MS medium for five days in darkness at $24 \pm 2^{\circ} \mathrm{C}$. After co-cultivation, the explants were transsfered onto fresh same composition medium containing cefotaxime (300 $\mathrm{mgl}^{-1}$ Tolicar, Jugoremedia, Zrenjanin, Serbia) to remove bacteria. Formed roots were excised from cotyledonary leaves and transferred onto half-strength MS medium lacking plant growth regulators and sub-cultured on new medium every 30 days. The untransformed roots grown on the same medium were used as the controls.

\subsection{Time-course of growth}

A time course experiment was started with $0.15 \mathrm{~g}$ fresh weight (FW) of 15 days-old hairy root inoculated into 100 Erlenmayer flaks containing $40 \mathrm{ml}$ half-strength liquid MS medium, on a gyratory shaker (110 r.p.m.), at $24 \pm 2^{\circ} \mathrm{C}$, in the dark. Measurements were performed by harvesting roots every 5 days during 35 days of culture. The experiment was done in triplicate.

\subsection{Statistical analysis}

The data are presented as average values with their standard error. Means were compared by one-way analysis of variances (ANOVA).

\subsection{GUS histochemical assay}

GUS histochemical assays were performed using the method described by Jefferson et al. [22]. For assays, hairy roots were placed into individual wells of a 96-well microtitre plate, each well containing $200 \mu \mathrm{l}$ of X-Gluc substrate at $\mathrm{pH} 7.0$ and incubated for $24 \mathrm{~h}$ at $37^{\circ} \mathrm{C}$ in the dark. 


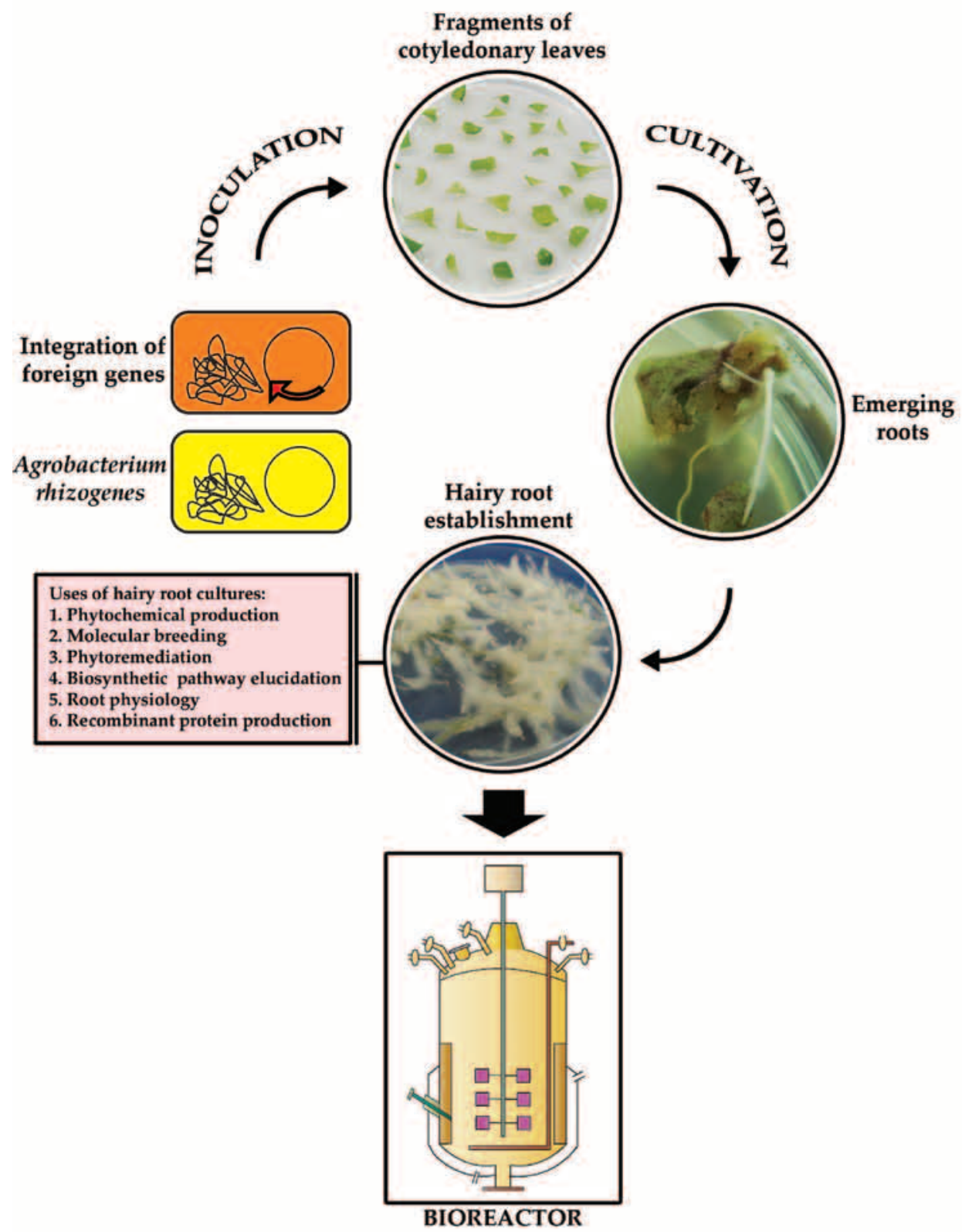

Figure 1. Production and diverse uses of hairy root cultures. 
TL

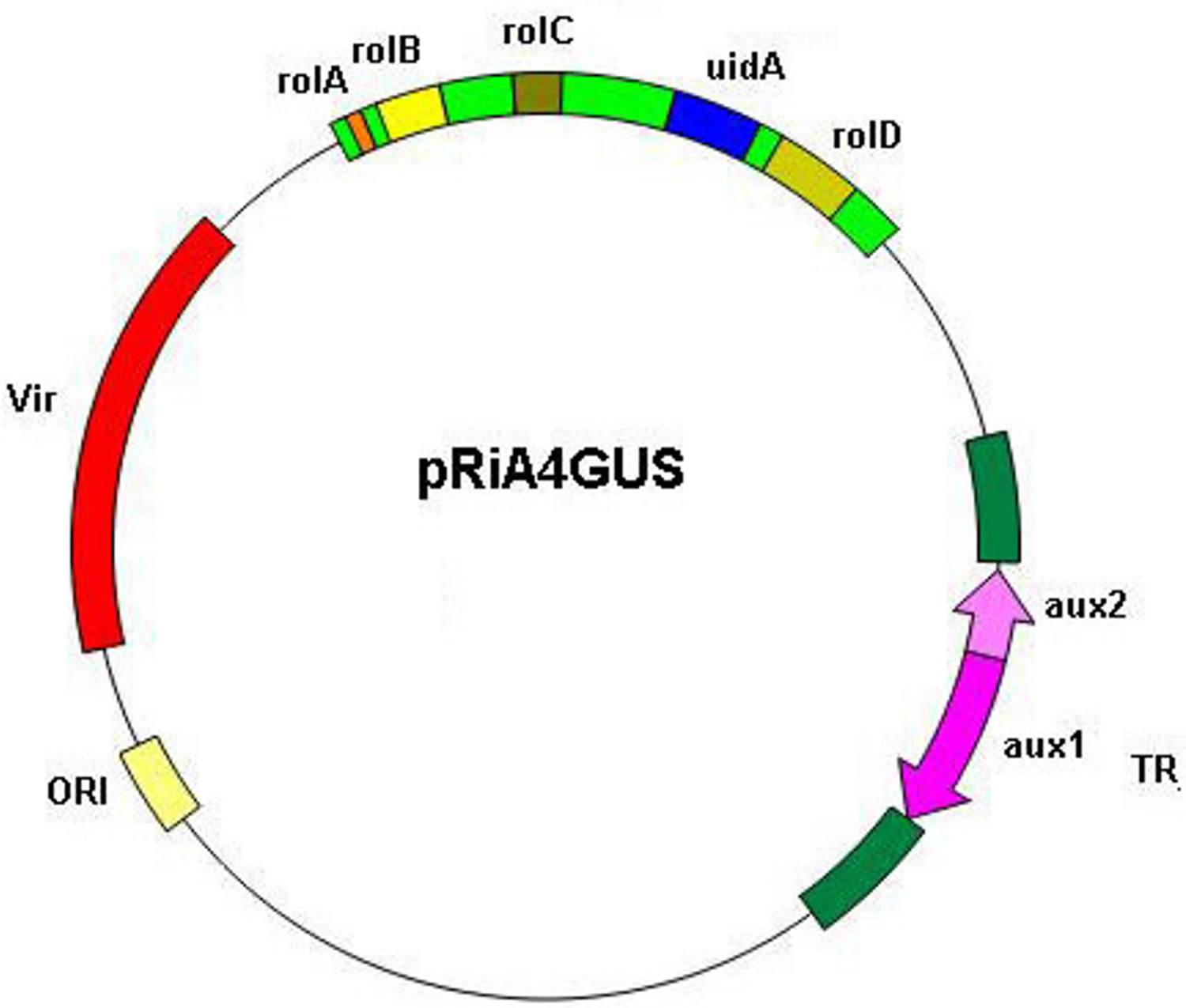

Figure 2. Diagram of pRiA4GUS with key genes.

\subsection{PCR analysis}

To confirm the transformation, genomic DNA was isolated from $200 \mathrm{mg}$ of fresh hairy root using CTAB method described by Zhou et al. [23]. The following primers specific to the uidA, rolA, rolB and rolC genes (Table 1) were used for PCR. To confirm the absence of Agrobacterium from hairy root lines, PCR was carried out using primers specific for virD1 gene (Table 1), located outside the T-DNA. PCR parameters were: initial denaturation temperature of $95^{\circ} \mathrm{C}$ for $5 \mathrm{~min}$ followed by 40 cycles of denaturation at $95^{\circ} \mathrm{C}$ for $1 \mathrm{~min}$, annealing at $60^{\circ} \mathrm{C}$ for $1 \mathrm{~min}$, and extension at $72^{\circ} \mathrm{C}$ for $2 \mathrm{~min}$, with a final extension at $72^{\circ} \mathrm{C}$ for 10 min using a thermal cycler (Techne, Genius). The amplified DNA products were visualized after electrophoresis on a $1.5 \%(\mathrm{w} / \mathrm{v})$ agarose gel stained with ethidium bromide. Non- transformed roots, and A. rhizogenes A4M70GUS, were used as negative and positive control, respectively.

\section{Results and discussion}

\subsection{Characterization of cultured hairy root lines}

Roots appeared on cotyledon leaves of both cultivars lettuce 10 days after inoculation with $A$. rhizogenes A4M70GUS. The hairy roots were sub-cultured on a medium with cefotaxime 30 days after the inoculation. Every single root was considered as one line. After 30 days the percentage of explants which formed roots was very high $(96.7 \%$ in Nansen and $91.2 \%$ in Ljubljanska ledenka). Similar transformation efficiency with A. rhizogenes A4M70GUS were reported earlier 
Table 1. List of primers used for PCR analyses in this study

\begin{tabular}{c|cc}
\hline Gene & Primer sequences 5' - 3' & Size of amplified fragment (bp) \\
\hline \hline uidA & CCC GGC AAT AAC ATA CGG CGT G & 366 \\
& CCT GTA GAA ACC CCA ACC CGT G & 441 \\
virD1 & ATG TCG CAA GGC AGT AAG & \multirow{2}{*}{ CAA GGA GTC TTT CAG CAT G } \\
rolA & GTT AGG CGT GCA AAG GCC AAG & 348 \\
& TGC GTA TTA ATC CCG TAG GTC & 342 \\
rolC & AAA GTC TGC TAT CAT CCT CCT ATG & 342 \\
& AAA GAA CGT GCA AGC TAC CTC TCT & \\
\hline
\end{tabular}

by Sretenović-Rajčić et al. [24] and Milošević et al. [25]. However, the effects of growth regulators on lettuce regeneration have not been fully evaluated, and no simple general procedure for the transformation of lettuce exists [17]. The efficiency of hairy roots formation depended on the strain of $A$. rhizogenes used and its interaction with plant species and tissue type $[4,26,27]$. Most plant tissues and organs, including the hypocotyl, leaf, stem, stalk, petiole, shoot tip, cotyledon, protoplast, storage root, and tuber, have shown capacity to be infected and genetically transformed by $A$. rhizogenes, with the resulting production of hairy roots $[6,28-30]$. However, the response varied depending on the $A$. rhizogenes strain and its interaction with the plant species and tissue type. In our experiments cotyledonary leaves of 7-days old seedlings were adequate explants. Momčilović et al. [31] used four species Gentiana (G. acaulis, G. cruiciata, G. lutea and G. purpurea) for the inoculation of shoots, leaves or decapitated stems with A. rhizogenes. Only shoots a few $\mathrm{cm}$ long responded by producing hairy roots, while others failed to respond.
The hairy root lines of lettuce grew on agar solidifid and liquid plant growth regulators-free medium, showing the typical features of hairy roots, plagiotropic growth, large number of root hair and lateral branches (Figure 3). The hairy root lines showed considerable phenoypic variations, particularly growth rate (Figure 4) and roots morphology. N2 line exhibited circularly hairy root growth on Petri dish in all subcultures. Some hairy roots were thin, with usual lateral roots and many root hairs (exsample line Ljubljanska ledenka 2). Nontransformed root cultures ( $\mathrm{Nc}$ and Ljlc) had a very low growth rate. Morphological differences were observed not only between different cultivars of lettuce, but also between different lines (Figure 3). Similar observations were reported for $G$. lutea, Impatiens hawkerii $[25,31]$. In the early 1990s, it was demonstrated that a combination of rolA, ro/B and ro/C loci was sufficient to produce the hairy root phenotype, depending on plant species, tissue type and transformation conditions [27].

Injuries of plant tissue are a necessary precondition for the successful genetic transformation mediated by genus Agrobacterium. They present sites for
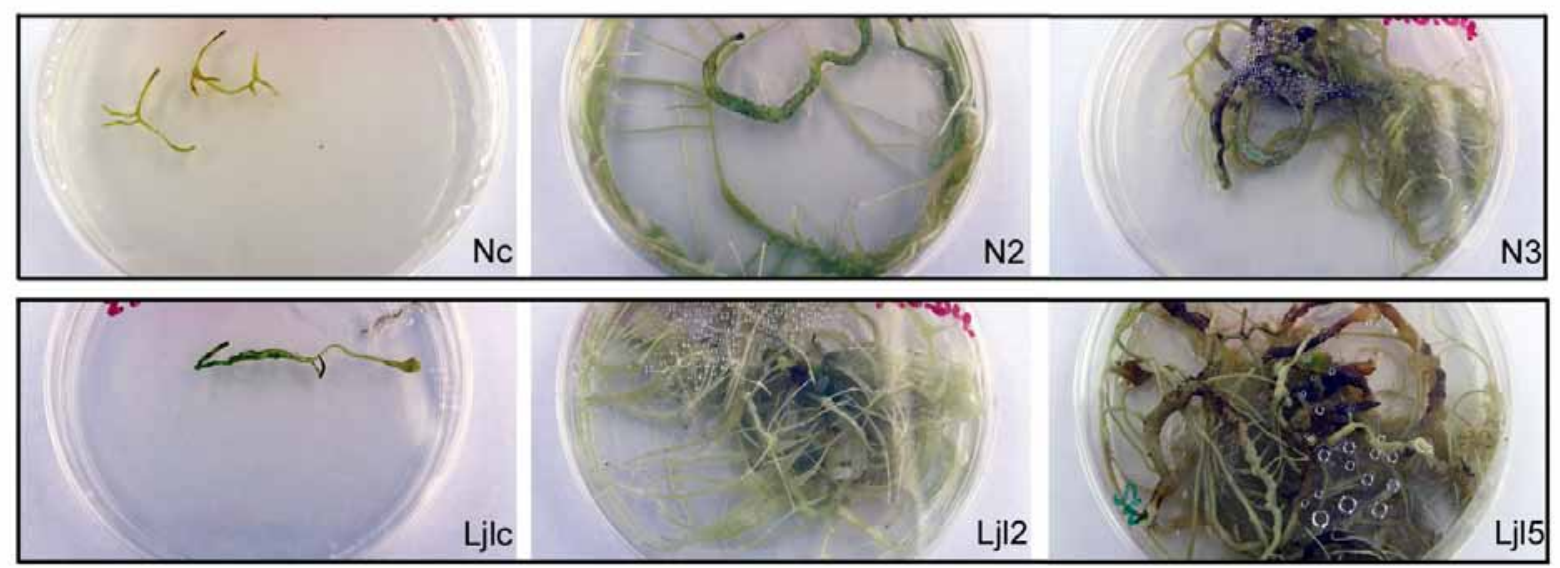

Figure 3. Growth of four weeks old hairy root culture of lettuce (Nc - Nasen control, N2, N3, Ljlc - Ljubljanska ledenka control, Ljl2, Ljl5). 


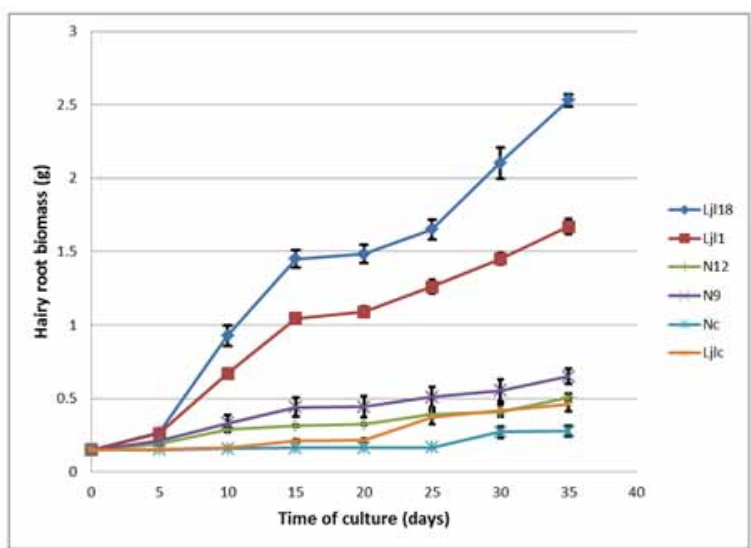

Figure 4. Time course of growth of L. sativa cv. Nansen and Ljubljanska ledenka fresh weight hairy root lines. Each point represents the mean of three replicates \pm SD. Time of culture: 35 days.

the production of chemotactic signals which make bacterial transfer through the cell wall much easier, which is considered to represent a barrier [32]. Injuries of cotyledonary leaves caused by cutting probably contributed to high efficiency of induction of hairy root.

Substantial differences in the growth rate and biomass production among seven hairy root lines of each cultivar were observed after 35 days in culture. Index of the biomass increase varied considerably, ranging from $0.50 \mathrm{~g}$ per $40 \mathrm{ml}$ half-strength liquid MS (Nansen 12 line) to $2.53 \mathrm{~g}$ (Ljubljanska ledenka 18 line). Line Ljubljanska ledenka 18 was found best for biomass accumulation, which was 5.5-fold higher than that of the control roots (Figure 4) and thus it was selected for further study of phytoremediation phenol from mini bioreactor systems. Tobacco hairy roots are able to remove phenol from solutions with its increasing concentrations (100-800 $\mathrm{mg} \mathrm{l}^{-1}$ ) [15]. However, Brassica napus hairy roots were able to remove phenol concentrations up to $500 \mathrm{mg} \mathrm{l}^{-1}$, in the presence of $\mathrm{H}_{2} \mathrm{O}_{2}$, reaching high removal efficiency, within $1 \mathrm{~h}$ of the treatment and over a wide range of $\mathrm{pH}$ (4-9) [10]. Therefore, the variation in growth increment was disinguishable not only between the two examined lettuce cultivars, but also among different lines of the same cultivar. Among 14 lines (two the fastest growing lines from both cultivars and their controls are shown in Figure 4) extensively studied, in terms of biomass production line, Ljubljanska ledenka 18 grew more rapidly and branched more frequently than all others. Opposite to this line, growth analyses showed that line Nansen 12 had the lowest response. The variation in morphological and growth characteristics can also be attributed to the effect of rol genes. Line Nansen 12 has only ro/C, while Ljubljanska ledenka 18 has three rol genes. Combination of rol genes is more efficient compared to their individual action, and induction of roots and their growth is more successful when rol genes act together, considering that they act synergistically [33]. $R o l$ genes can take part in biosynthesis of plant growth regulators or they can increase plant sensitivity to those regulators [34].

All 14 lines demonstrated moderate production of biomass: the ratios of final fresh weights to their initial fresh weights were 3.33 to 16.87 for each subculture. Non-transformed root grew slowly and showed small growth rate (control of Nunsen 1.85 and Ljubljanska ledenka 3.07 times). Few studies have been performed on the analyses of hairy root growth [25,31,35-39]. Similar difference in growth rate of hairy roots lettuce was observed earlier [39]. The ratios of the final fresh weights to initial fresh weights of hairy roots $L$. virosa in Stojakowska et al. [39] investigation were 15.8. Hairy roots of $I$. hawkerii has biomass 26 times higher then non-transformed roots in liquid MS medium [25], biomass $G$. lutea was 6.9 to 18.8 times higher than control [31] but the highest ratio was found in Scutellaria baicalensis - 37 times [38]. In comparing of the two $L$. sativa cultivars, it seems that hairy root regeneration from cotiledonary leaves was better in Nansen, but growing of hairy roots in liqud medium was better in Ljubljanska ledenka cultivar.

\subsection{GUS assay}

GUS expression was used to evaluate the factors affecting transformation efficiency. All lines induced by $A$. rhizogenes A4M70GUS were subjected to GUS histochemical assay to determine the potential of lettuce cultivars to react with GUS stain. Positive X-gluc staining reaction was obtained for all lines, although the intensity of colour varied from lines to lines. GUS reaction was negative in the untransformed control roots (Figure 5). Positive GUS reaction is not reliable evidence of $\beta$-glukuronidase activity considering that endogenous enzyme in plant tissue can use same substrate and that most plant species express that enzyme at least in some tissues under certain conditions [40,41]. As a consequence this result is acceptable only as an indicator of the genetic transformation and further confirmed using other techniques or methods (e.g. by PCR analysis).

\subsection{PCR analysis}

All lines which failed to react with GUS stain were subjected to PCR analysis. All 15 lines, seven Nansen (Figure $6 \mathrm{~A}$ ) and eight Ljubljanska ledenka (Figure 6 B) showed positive PCR amplification of uidA fragment of 
366 bp (Figure 6). This result confirm the results of GUS assay. Presence of rolA gene was confirmed in five lines of c.v. Nansen and six of Ljubljanska ledenka (Figure 6).

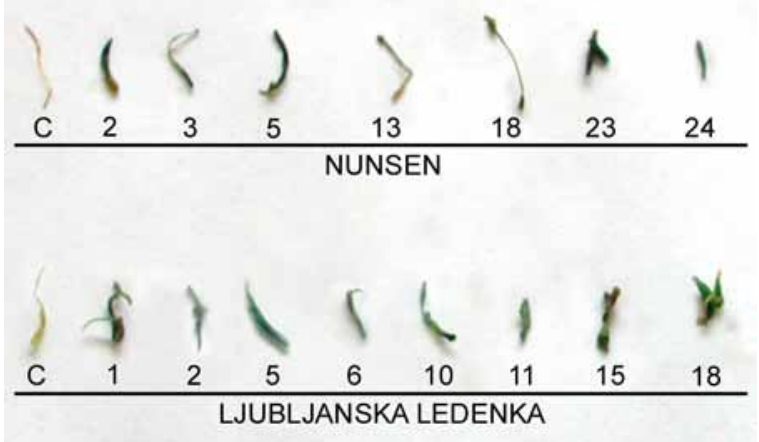

Figure 5. GUS histochemical assay of hairy root showing blue colouration in 15 lines lettuce and absence of GUS expression in control roots.
Whereas control roots did not shown any positive signal for 348bp fragment of ro/B gene, two hairy root lines of Nansen and six of Ljubljanska ledenka were positive (Figure 6) indicating integration of this gene into the host cell genome. Amplicon of 342 bp corresponding to the rolC gene was obtained in the DNA of four Nansen and seven Ljubljanska ledinka lines (Figure 6). The presence of residual contaminating bacteria was checked by PCR analysis using virD1 specific primer sequence. No amplification product was detected in any hairy root lines (Figure 6). However, positive control (Ar) showed amplificon of $441 \mathrm{bp}$ virD1 fragment.

Different characteristics among hairy root lines might be related to variation of the T-DNA insertion, i.e., of the copy number and location of Ri genes integrated into the plant genom [42]. The perfect transformant would

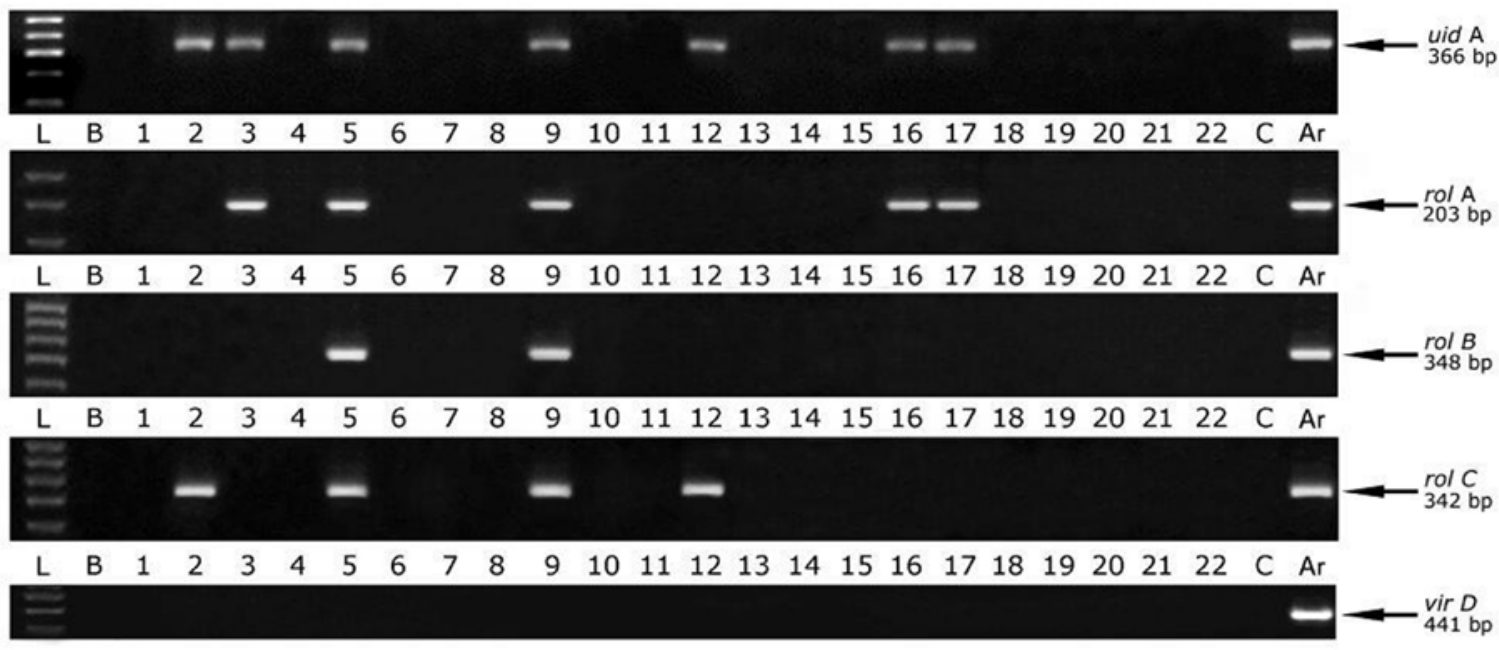

A
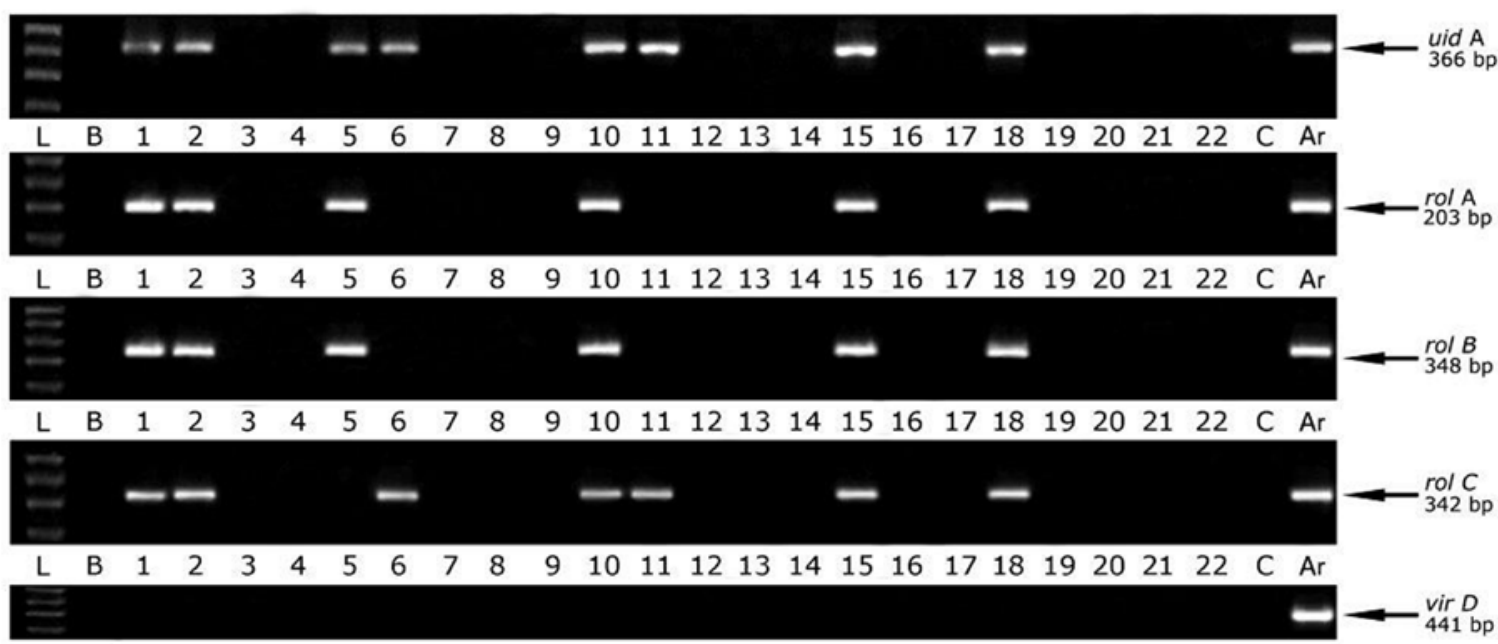

B

Figure 6. PCR analysis of genomic DNA isolated from hairy roots of lettuce cv. Nansen (A) and Ljubljanska ledenka (B). Lanes: L - ladder, B blanc, 1-22 - hairy roots lines, C - untransformed control roots, $\mathrm{Ar}$ - positive control (pRiA4M70GUS) 
contain a single copy of the transgene that would segregate as a mendelian trait, with uniform expression from one generation to the next. Ideal transformants can be found with difficulty, depending upon the plant material to be transformed and to same extent on the nature and the transgene complexity [43]. The different levels of their expression among hairy root lines could alter the endogenous auxins/cytokinins ratio or sensitivity to the previous plant growth regulator balance of each genotype [25, 44]. The estimation of a number of rol gene copies in genome of hairy root from lettuce, expression of rol and aux genes, and their influence on the morphology of obtained strains will be a subject of future studies. Plant regeneration from hairy roots on the plant growth regulators-free media often occurs spontaneously G. cruciata [27,31], Blackstonia perfoliata [48], Brassica oleracea [24], which is not the case in lettuce (similar to G. lutea, G. acaulis and G. puntata [31,45], I. hawkerii [25] and Beta vulgaris [46]. During the shoot regeneration process, plant growth regulators played a very important role. The ability of lettuce cultivars to regenerate may vary with the concentration and combination of growth regulators,

\section{References}

[1] Curtis I., Genetic transformation-Agrobacterium, In: Davey M. R. and Anthony P. (Eds.) Plant Cell Culture, Essential Methods, 199-215, WileyBlackwell, 2010

[2] FAO (2006): http://faostat.fao.org/faostat/sevlet/. Cited 20 April 2006.

[3] USDA (2005) Vegetables. Annual Summary 01.27.06. National Agricultural Statistics Service. http://usda.mannlib.cornell.edu/reports/nassr/ fruit/pvgbban/. Cited 2006.

[4] Veena V., Taylor G.C., Agrobacterium rhizogenes: recent developments and promising applications. In Vitro Cell. Dev. Biol-PI., 2007, 43, 383-403

[5] Zdravković-Korać S., Muhovski Z., Druart P., Ćalić D., Radojević Lj., Agrobacterium rhizogenes-mediated DNA transfer to Aesculus hippocastanum $\mathrm{L}$. and the regeneration of transformed plants. Plant Cell Rep., 2004, 22, 698-704

[6] Giri A., Narasu M.L. (2000) Transgenic hairy roots. Recent trends and applications. Biotechnol. Adv., 2000, 18, 1-22

[7] Guillon S., Trémouillaux-Guiller J., Pati P.K., Rideau M., Gantet P., Hairy root research: recent scenario and exciting prospects. Curr. Opin. Plant Biol., 2006, 9, 341-346 particularly auxins and cytokinins [39]. Stimulatory effect of hormones on induction of organogenesis and shoot morphogenesis is goal of our future investigation.

Hairy root of various plant species can significantly detexify pesticides, antibiotics and other varius toxic industrial effluents $[4,7]$. Hairy root also have been used to compare the tolerance and removal of high levels of phenols [13,47]. Also, all regenerants from hairy root showed an increased ability to produce roots [49], which was very helpful in increasing root formation from the lettuce that can be using in phytoremediation process. In this context, first step of our investigation will be removal of phenol with hairy roots of lettuce from liquid medium for plant gowth with aim to developing model systems for bioreactors and hidroponic plant growth. This technology has been recognized as a cheap and eco-friendly alternative.

\section{Acknowledgments}

This research was supported by the Ministry of Education, Science and Technological Development of the Republic of Serbia, Project TR-31019.

[8] Ono N.N., Tian L., The multiplicity of hairy root cultures: Prolific possibilities. Plant Sci., 2011, 180, 439-466

[9] Shih S.M.-H., Doran P.M., In vitro propagation of plant virus using different forms of plant tissue culture and modes of culture operations. J. Biotechnol., 2009, 143, 198-206

[10] Coniglio M., S., Busto V. D., González P. S., Medina M. I., Milrad S., Agostini E., Application of Brassica napus hairy root cultures for phenol removal from aqueous solutions. Chemosphere,2008, 72, 1035-1042

[11] Doran P.M., Application of plant tissue cultures in phytoremediation research: incentives and limitations. Biotechnol. Bioeng., 2009, 103, 60-76

[12] González P. S., Agostini E., Milrad S. R., Comparison of the removal of 2,4-dichlorophenol and phenol from polluted water, by peroxidases from tomato hairy roots, and protective effect of polyethylene glycol. Chemosphere., 2008, 70, 982-989

[13] González P. S., Maglione G. A., Giordana M., Paisio C. E., Talano M. A., Agostini E., Evaluation of phenol detoxification by Brassica napus hairy roots, using Allium cepa test. Environ. Sci. Pollut. Res.2012, 19, 482-491 
[14] Suresh B., Ravishankar G.A., Phytoremediation - a novel and promising approach for environmental clean-up. Crit. Rev. Biotechnol., 2004, 24, 97-124

[15] Sosa Alderete L.G., Ibáñez S.G., Agostini E., Medina M.I., Phytoremediation of Phenol at pilot scale by tobacco hairy roots. Int. J. Environ. Sci., 2012, 3, 398-407

[16] Suza W., Harris R.S., Lorence A., Hairy roots: from high-value metabolite production to phytoremediation. Electron J. Int. Biosci., 2008, 3, 57-65

[17] Lim W., Park J., Park S., Re-evaluation of the effects of growth regulators on callus induction and shoot regeneration in Agrobacterium-mediated transformation of lettuce. Acta Physiol. Plant., 2011, 33, 1631-1637

[18] Pileggi M., Pereira A. A. M., Silva J. dos S., Pileggi S. A. V., Verma D. P. S., An Improved Method for Transformation of Lettuce by Agrobacterium tumefaciens with a gene that confers freezing resistance. Braz. Arch. Biol. Techn., 2001, 44, 191-196

[19] Ahmed B. M., Akhter M. S., Hossain M., Islam R., Choudhury T. A., Hannan M. M., Razvy M. A., Ahmad I., An efficient Agrobacterium-mediated genetic transformation method of lettuce (Lactuca sativa L.) with an aphidicidal gene, Pta (Pinellia ternata Agglutinin). Middle East J. Sci. Res., 2007, 2, 155-160

[20] Matvieieva N. A., Vasylenko M. Y., Shakhovsky A. M., Kuchuk N. V., Agrobacterium-mediated transformation of lettuce (Lactuca sativa L.) with genes cording bacterial antigens from Mycobacterium tuberculosis. Cytol Genet., 2009, 43, 94-98

[21] Van Larebeke N., Genetello C.H., Hernalsteens J.P., De Picker A., Zaenen I., Messens,E., Van Montagu M., Shell J., Transfer of Ti plasmid between Agrobacterium strains by mobilization with the conjugative plasmid RP4. Mol. Genet., 1977, 152, 1119-1124

[22] Jefferson R. A., Kavanagh T. A., Bevan M. W., GUS fusions: $B$-glucuronidase as a sensitive and versatile gene fusion marker in higher plants. EMBO J., 1987, 6, 3901-3907

[23] Zhou X., Guangcheng C., Rufa L., Yongru S., Wenbin L., A rapid and efficient DNA extraction method of genus Fagopyrum for RAPD analysis. Proc IPBA, Rougla, 171-175, 1994.

[24] Sretenović-Rajčić T., Ninković S., Miljuš-Đukić J., Vinterhalter B., Vinterhalter D., Agrobacterium rhizogenes-mediated transformation of Brassica oleracea var. sabauda and B. oleracea var. capitata. Bio Plantarum., 2006, 50, 525-530
[25] Milošević S., Subotić A., Cingel A. Jevremović S. and Ninković $S$. Efficient genetic transformation of Impatiens hawkerii Bull. (Balsamiaceae) using Agrobacterium rhizogenes. Arch. Biol. Sci., 2009, 61, 467-474

[26] Sinkar V.P., Pythoud F., White F.F., Nester W.E. and Gordon P.M., rol A locus of the Ri plasmid directs developmental abnormalities in transgenic tobacco plants. Gene. Dev., 1988, 2, 688-697

[27] Christey M.C., Use of Ri-mediated transformation for production of transgenic plants. In Vitro Cell Dev.-Pl., 2001, 37, 687-700

[28] Yazaki K., Tanaka S., Matsuoka H., Sato F., Stable transformation of Lithospermum erythrorhizon by Agrobacterium rhizogenes and shikonin production of the transformants. Plant Cell Rep., 1998, 18, 214-219

[29] KrolickaA., Stanisyewska I., Bielawski K., Malinski E., Szafranek J., Lojkowska E., Establishment of hairy root cultures of Ammi majus. Plant Sci., 2001, 160, 259-264

[30] Azlan G.J., Marziah M., Radzali M., Johari R., Establishment of Physalis minima hairy roots culture for the production of physalins. Plant Cell Tiss. Org., 2002, 69, 271-278

[31] Momčilović I., Grubišić D., Kojić M., Nešković M., Agrobacterium rhizogenes-mediated transformation of four Gentiana species. Plant Cell Tiss. Org. Cult., 1997, 50, 1-6

[32] Gelvin S. B., Agrobacterium and plant genes involved in T-DNA transfer and integration. Annu. Rev. Plant. Phys., 2000, 51, 223-256

[33] Bulgakov V. P., Functions of rol genes in plant secondary metabolism, Biotechol. Adv., 2008, 26, 318-324

[34] Binns A.N., Costantino P., The Agrobacterium oncogenes. In: Spaink H., Kondorosi A., Hooykaas P.J.J. (Eds.), The Rhizobiaceae, 251-266 Kluwer Press, Holland, Dordrecht, 1998

[35] Bonhomme V., Laurain-Mattar D., Lacoux J., Fliniaux M.A., Jacquin-Dubreuil A., Tropane alkaloid production by hairy roots of Atropa belladona obtained after transformation with Agrobacterium rhizogenes 15834 and Agrobacterium tumefaciens containing rol A, B, C genes only. J. Biotech., 2000, 81, 151-158

[36] Tanaka N., Fujikawa Y., Aly M.A.M., Saneoka H., Fujit K., Yamashita I., Proliferation and rol gene expression in hairy root lines of Egyptian clover. Plant Cell Tiss. Org. Cult., 2001, 66, 175-182

[37] Lin H.W., Kwok K.H., Doran P.M., Development of Linum flavum hairy root cultures for production of coniferin. Biotech. Let., 2003, 25, 521-525 
[38] Tiwari R.K., Trivedi M., Guang Z.C., Guo G.Q., Zheng, G.C., Agrobacterium rhizogenes mediated transformation of Scutellaria baicalensis and production of flavoponoids in hairy roots. Biol. Plantarum., 2008, 52, 26-35

[39] Stojakowska A., Malarz J., Szewczyk A., Kisiel W., Caffeic acid derivatives from a hairy root culture of Lactuca virosa. Acta Physiol. Plant., 2012, 34, 291-298

[40] Hu C.Y., Chee P.P., Chesney R.H., Zhou J.H., Miller P.D., O'Brien W.T., Intrinsic GUS-like activities in seed plants. Plant Cell Rep., 1990, 9, 1-5

[41] Hodal L., Bochardt A., Nielsen J., Mattsson O., Okkels F., Detection, expression and specific elimination of endogenous $\beta$-glucuronidase activity in transgenic and non-transgenic plants. Plant Sci., 1992, 87, 115-122

[42] Doran P.M., Properties and applications of hairy - root cultures. In: Okasman- Caldenty K.M. and Barz W.H. (Eds.) Plant Biotechnology and transgenic plants, 143-162, New York, Mercel Dekker Inc, 2002

[43] Hansen G., Wright M.S., Recent advances in the transformation of plants. Trends Plant Sci., 1999, 4, 226-231

[44] Shen W. H., Petit A., Guern J., Tempe J., Hairy roots are more sensitive to auxin than normal roots. PNSA., 1988, 85, 3417-3421
[45] Vinterhalter B., Zdravković-Korać S., Ninković S., Mitić N., Janković T., Miljuš-Đikuić J., Vinterhalter D., Variability in shoot cultures regenerated from hairy roots of Gentiana punctate. Biol. Plantarum., 2011, 55, 414-422

[46] Ninković S., Djordjević T., Vinterhalter B., Uzelac B., Cingel A., Savić J., Radović S. Embryonic responses of Beta vulgaris L. Callus induced from transgenic hairy roots. Plant Cell Tiss Organ Cult., 2010, 103, 81-91

[47] Santos de Araujo B., Dec J., Bollag J.M., Pletsch M., Uptake and transformation of phenol and chlorophenols by hairy root cultures of Daucus carota, Ipomoea batatas and Solanum aviculare. Chemosphere., 2006, 63, 642-651

[48] Bjelović A., Rosić N., Miljuš-Đukić J., Ninković S., Grubušić D., In vitro regeneration and transformation of Blackstonia perfoliata. Biol. Plantarum, 2004, 48, 333-338

[49] Wu J., Wang Y., Zhang L.-X., Zhang X.-Z., Kong J., Lu J., Han Z.-H., High-efficiency regeneration of Agrobacterium rhizogenes-induced hairy root in apple rootstock Malus baccata (L.) Borkh. Plant Cell Tiss. Organ Cult., 2012, 111, 183-189 